\title{
Effect of conversational teaching on philosophical rings on elementary students' reflective thinking
}

\author{
Farideh Hamidi $^{1 *}$ iD , Mohammad Reza Imam Jomeh', Amir Nami ${ }^{2}$ \\ 1. Associate Professor of Psychology, Educational Sciences Department, Humanistic Faculty, Shahid Rajaee Teacher Training University, \\ Tehran, Iran \\ 2. MA Student of Educational Psychology, Educational Sciences Department, Humanistic Faculty, Shahid Rajaee Teacher Training Uni- \\ versity, Tehran, Iran
}

Recieved: 20 Mar. 2019

Revised: 6 Feb. 2020

Accepted: 14 Apr. 2020

\section{Keywords}

Reflective thinking

Philosophical conduct

Philosophy for children

\section{Corresponding author}

Farideh Hamidi, Associate Professor of Psychology, Educational Sciences Department, Humanistic Faculty, Shahid Rajaee Teacher Training University, Tehran, Iran

Email: Fhamidi@sru.ac.ir

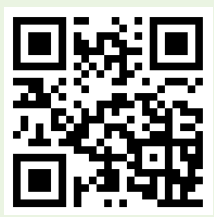

doi.org/10.30699/icss.22.2.120

\section{Abstract}

Introduction: The program of teaching philosophical thinking to children is a program for improving children's thinking. In this way, the learner, will discover the concepts, principles, rules and thus acquire the necessary knowledge without the help of the teacher. The present study aimed to investigate the effect of the teaching method of dialogue in philosophical study circles on the growth of thinking in sixth-grade boys in the Sangar district of Rasht city in Iran.

Methods: This experimental study was a pretest-posttest with control group. The statistical population consisted of all sixth-grade students in Sangar city. Sixty of them were selected by twostage cluster sampling and replaced by two groups of 30 experimental and control groups. For collecting data, the Questionnaire for Reflective Thinking (Kember, 2000) was used. Eight stories from Persian, religious, and international texts were selected for the experimental group to run an independent variable, which had a storyline in eight sessions and each session. Data were analyzed using descriptive statistics and ANCOVA covariance analysis.

Results: The results showed that teaching philosophical thinking positively and significantly affects children's reflective thinking. The impact effect of training was $37 \%$.

Conclusion: Therefore, using the philosophy of teaching method, children are trained to develop their thinking and reasoning skills in dialogue and to develop analytical thinking skills.

Citation: Hamidi F, Imam Jomeh M, Nami A. Effect of conversational teaching on philosophical rings on elementary students' reflective thinking. Advances in Cognitive Sciences. 2020;22(2):120-131. 


\author{
تاثير روش تدريس كفتكويى در حلقهاى كندوكاو فلسفى بر تفكر تاملى

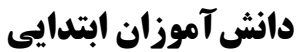 \\ فريده حميدى "*iD ، محمد رضا امام جمعه'، امير نامى'

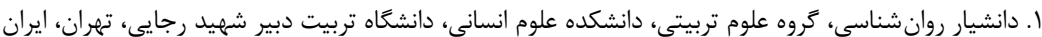

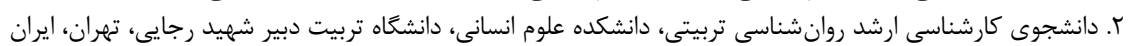

\section{דrus}

مقدمه: برنامئ آموزش تفكر فلسفى به كودكان، برنامهاى در جهت بهبود تفكر كودكان است. در اين روش يادكيرنده بدون كمك معلم، خود به كشف مفاهيه، اصول و قوانين مى يردازد و از اين طريق به دانشهاى لازم دست مى يابد. يروهش حاضر با هدف بررسى تاثير روش تدريس كفتتويى در حلقهاى كندوكاو فلسفى بر رشد تفكر تاملى دانش آموزان يسر קايه ششم منطقه سنكر از توابع شهرستان رشت در ايران انجام شد. روش كار: اين يزوهش از نوع آزمايشى با طح بِيشآزمون_يسآزمون با كروه كنترل بود. جامعه آمارى شامل كليه دانشآموزان پايه ششم شهر سنخر بود كه از ميان آنها •و نفر به روش نمونه كيرى خوشهاى دو مرحلهاى انتخاب شدند و

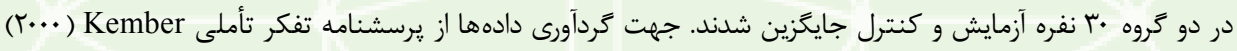
استفاده شد. به منظور اجراى متغير مستقل، هشت داستان از كتب كهن يارسى، مذهبى و متون بينالمللى براى كروه آزمايش انتخاب شد كه در هشت جلسه و هر جلسه يك داستان مورد كندوكاو قرار كرفت. دادها با استفاده از تحليل كوواريانس ANCOVA مورد تجزيه و تحليل قرار كرفت. يافته ها: نتايج نشان داد كه برنامههاى آموزش فلسفهورزى (فبك) بر ميزان بر رشد تفكر تاملى دانش آموزان تاثير مثبت

$$
\text { و معنادارى كذاشته است. ميزان اندازه اثر آموزشها در تفكر تاملى WV درصد بود. }
$$

نتيجه كيرى: بنابراين مى توان نتيجه كرفت با استفاده از روش تدريس كفتگويى، كودكان به كونهاى ثبروش مى يابند كه بتوانند مهارت تفكر و استدلال خود را در جريان كفتتخو بالا ببرند و مهارت تفكر تحليلى ييدا كنند.
\end{abstract}

دريافت: IrqV/Ir/rq

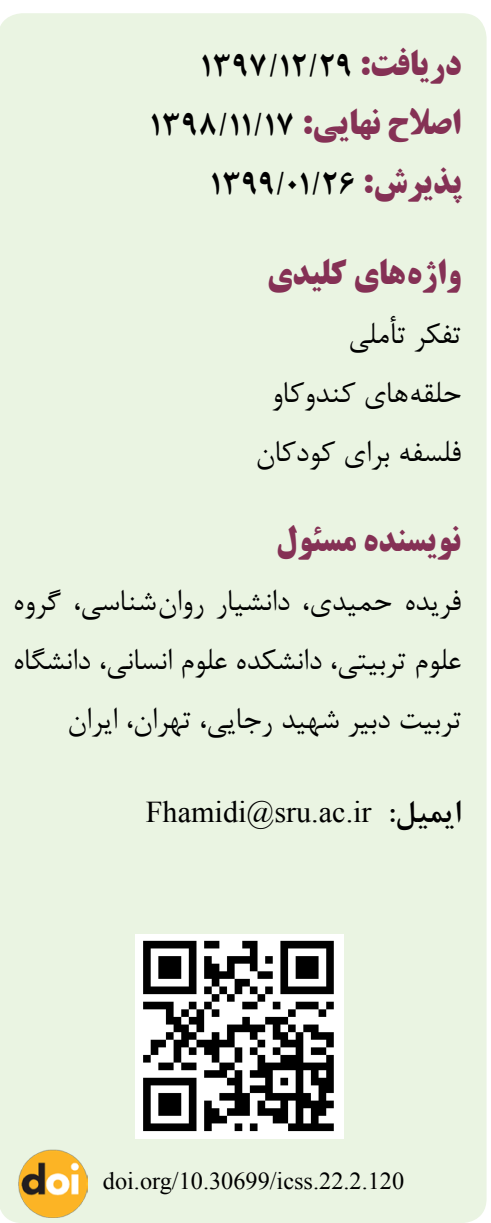

مقلدمه

ارسطو و ديخر انديشمندان نيست، بلكه آموزش نوعى كفتتوى گروهى است كه كلاس را از شكل سنتى معلم محور و انتقال مطالب از پيش آماده شده به شاكردان خارج مى كنند (1). فلسفه به كودكان امكان مى دهد تا به جاى موضوعات، درستى آنها را سبك و سنگين كنند و در مورد آنها داورى كنند (r). يكى از زيرساخت هاى توسعه انسانى
وازه "فلسفه" بركرفته از زبان يونانى باستان و به معنى عشق به حكمت است ( (1). يونانيان، فلسفه را شيوه پرسش و حل مسئله مى دانستند و به مطالعه جراها روى مى آوردند. ممكن است بعضى تصور كنند كه نمى توان به كودكان فلسفه آموخت. اما بايد توجه داشت منظور از آموزش فلسفه به كودكان، آموزش فلسفه كلاسيك افلاطون، كانت، 
دانش آموزان و معلمان ارتباط شفاهى بهترى داشـته باشــند (^).

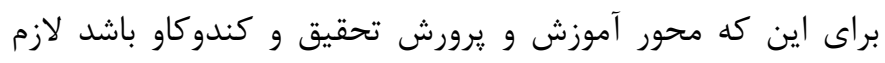

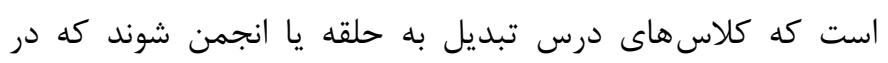

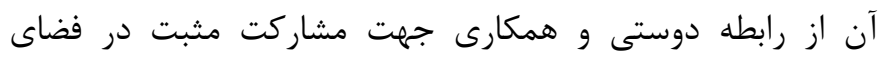

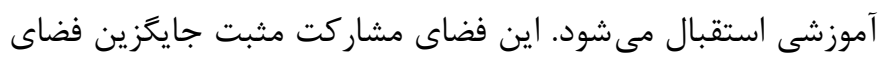

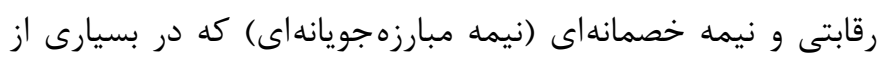

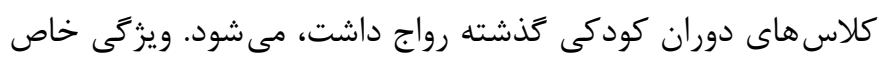

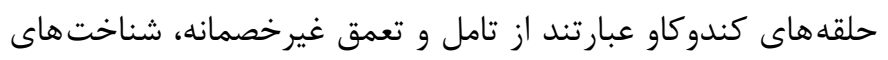

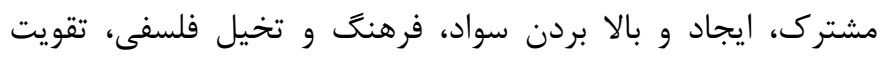

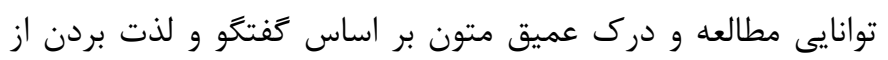

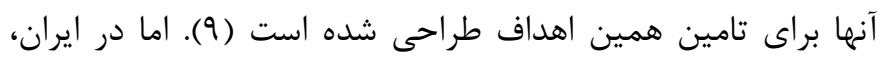

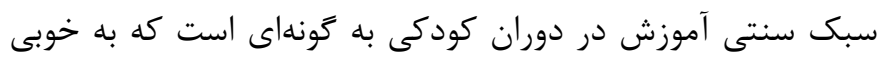

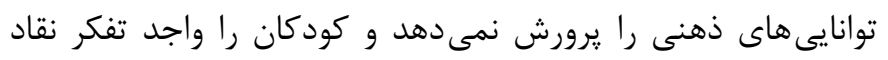

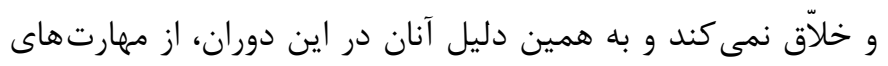

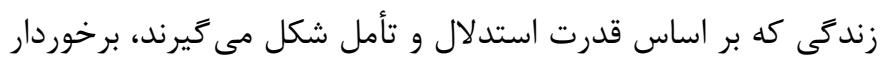

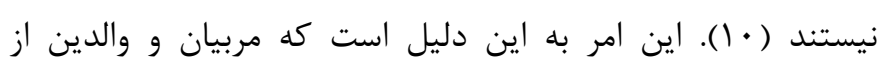

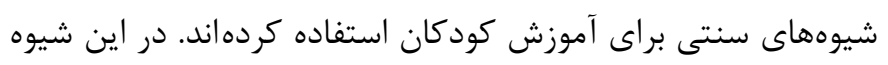

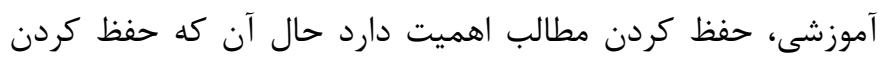

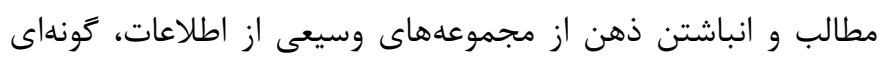

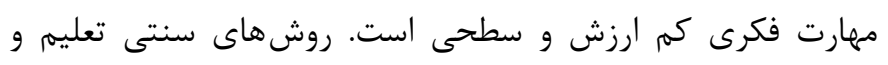
تاكيد بر حافظه محورى (Axial memory) باعث رشد دانش دانش آموزان

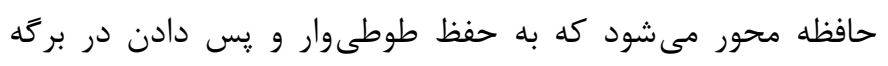

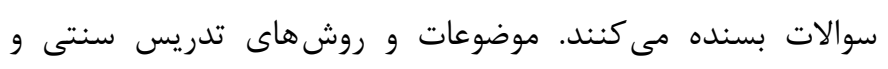

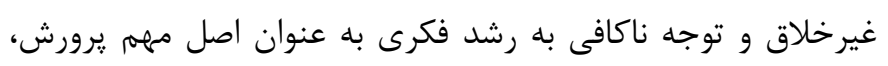

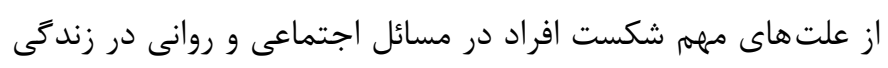

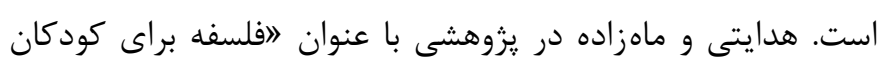
و مهارت حل مسئله اجتماعى" نشان دادند كه مشاركت در برنامه دمانه

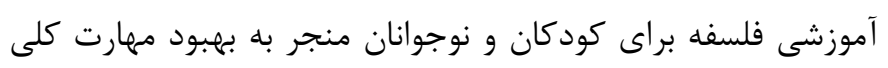

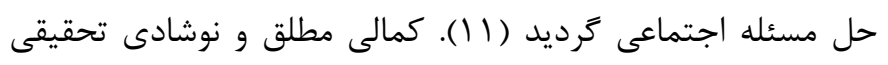

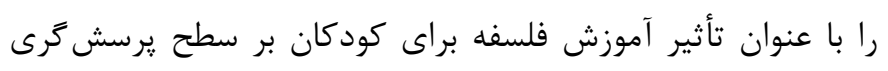

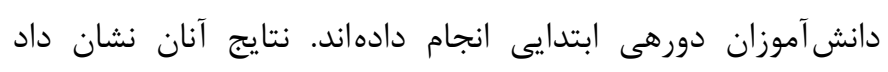

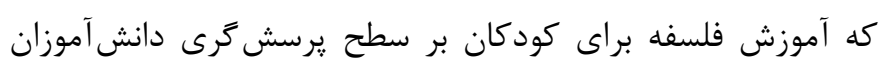

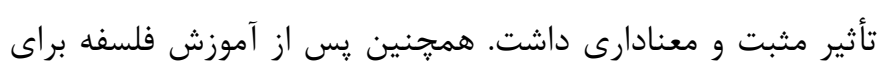

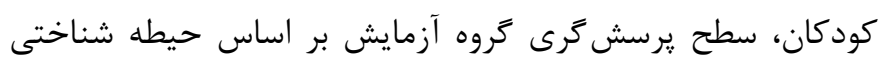

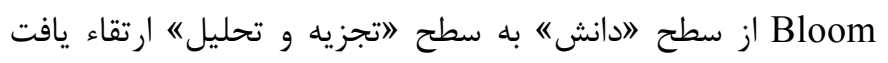

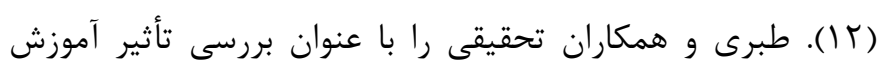
فلسفهورزى بر روحيه يرسش گرى و مهار خشمى در دانش آموزان انجام
و فراگير، رشد مهارتهاى فكرى است و از مولفه هاى تأثير خذار در آموزش و يرورش و آموزش تفكر تأملى (Reflective Thinking) برنامه فلسفه براى كودكان است (ץ). مفهوم تفكر تأملى را اولين بار

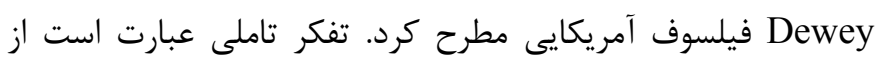

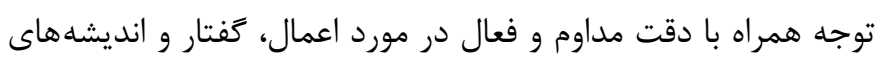

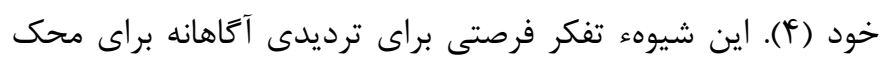

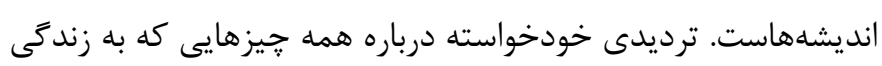

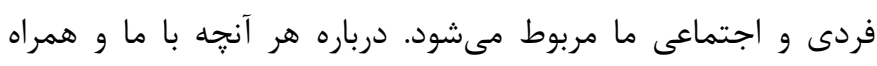

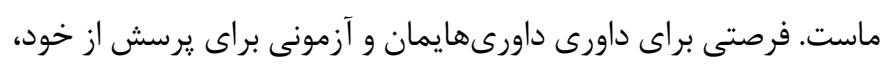

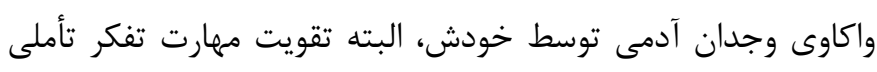
نيازمند تمرين است (ه). لزوم تفكر انتقادى (Critical Thinking)

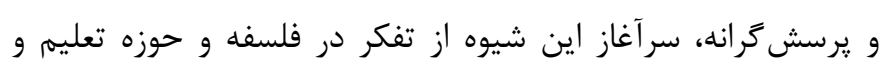

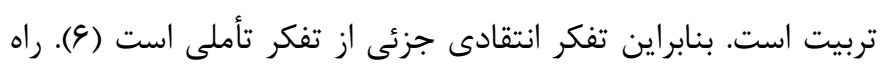

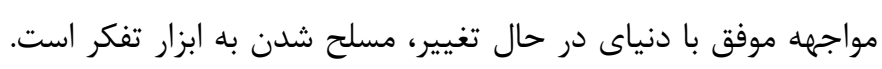

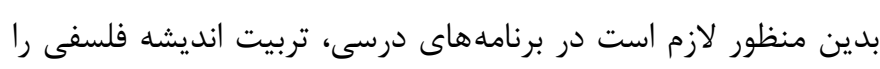

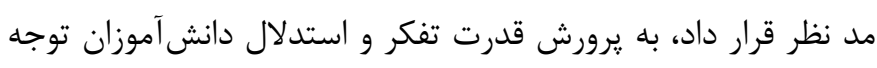

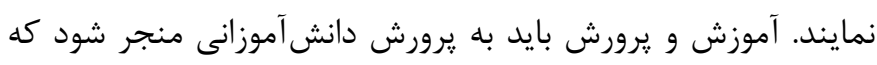
توانايى بازشناسى عقايد و نظرات صحيح از ناصحيح را دارند و در اين باني

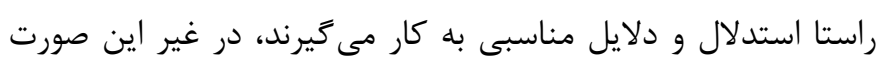

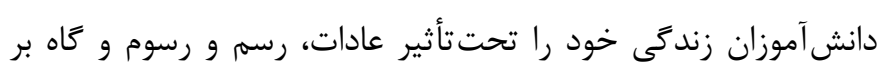
مبناى اتفاقات ييش خواهد برد (بّ).

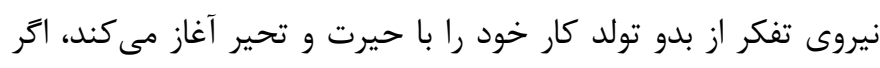

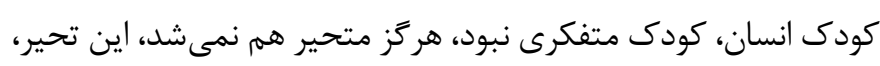

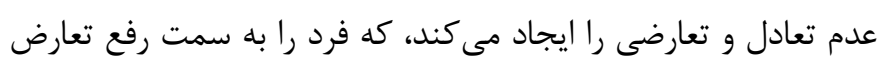

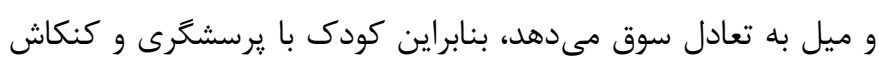

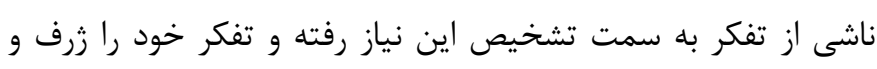

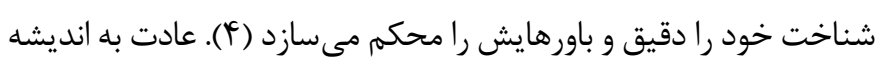

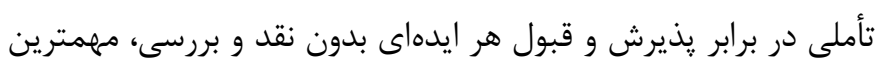

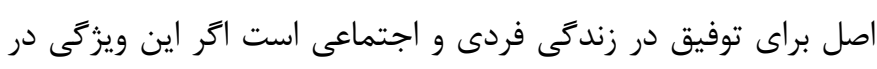

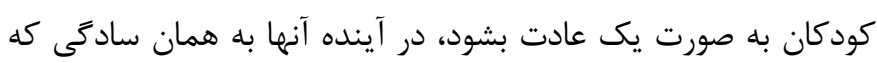

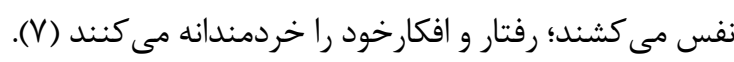

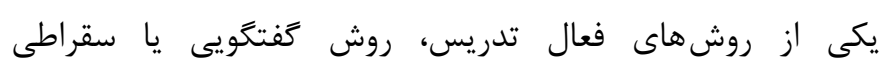
(Dialogue or Socratic Method) صحبت نمى كند؛ سؤال مى كند و شاكردان سخن مى كويند. اما

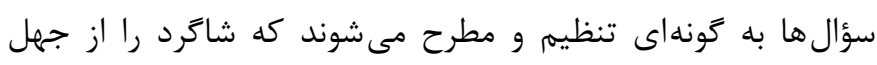

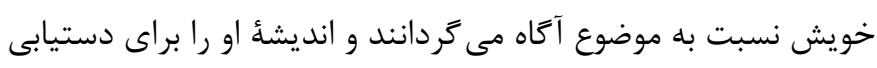

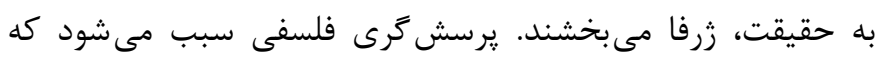


براى رسيدن به اين هدف كنجاندن مفاهيم فلسفى و اخلاقى در قالب

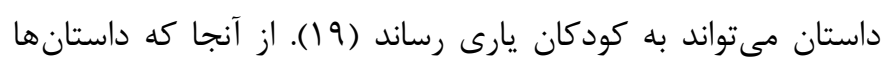

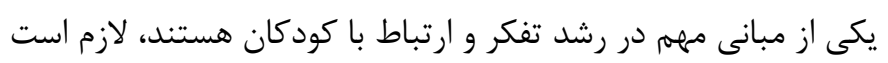

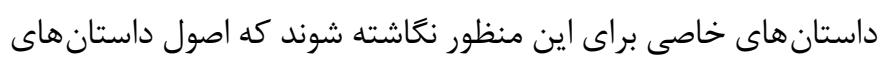

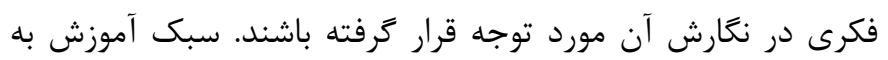

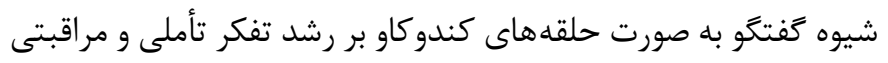

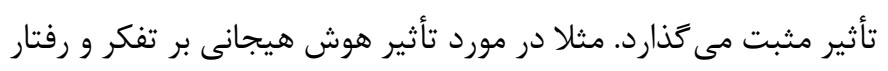

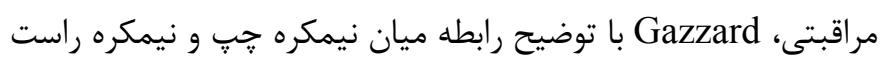
مغز، خاطرنشان مى كند، ارتباط معنادارى ميان فلسفه و هوش هيجانى

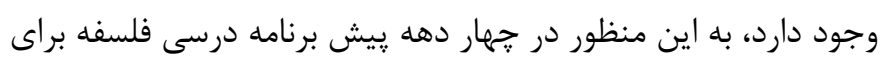

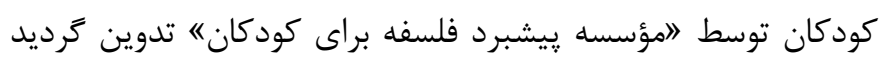

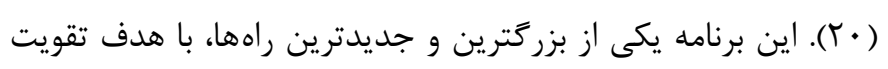

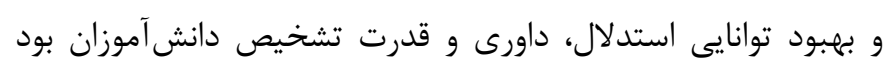

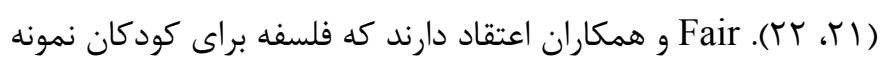

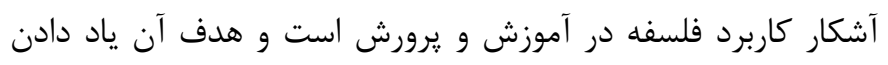

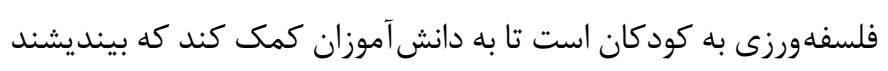

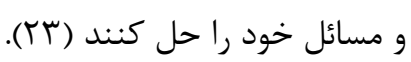

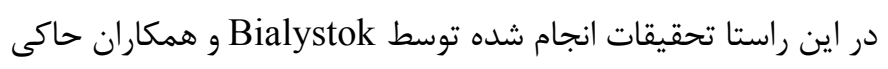

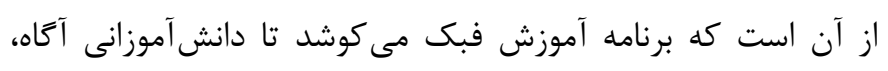

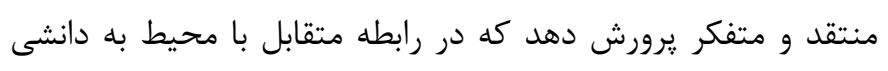

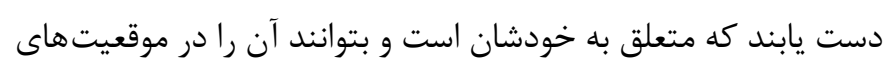

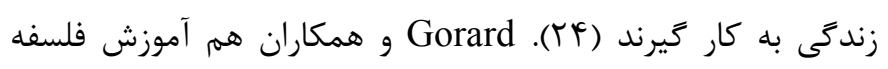

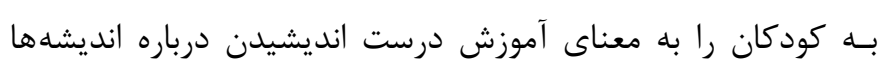
از طريق جستجو به روش علمى براى درست زيستن مى دانند (Yه) Cullen

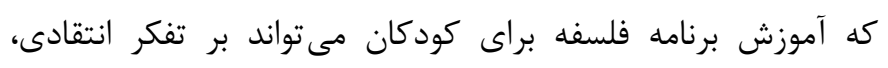

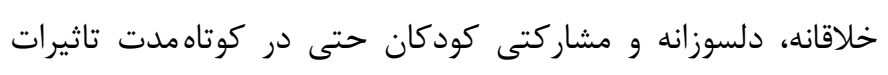

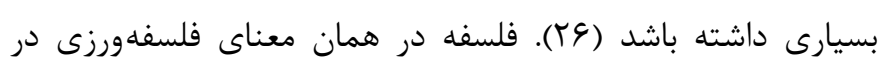

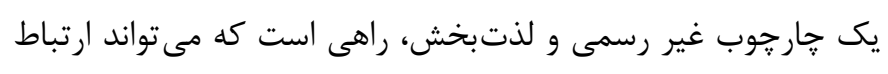

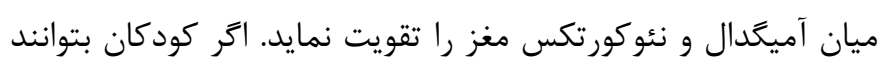

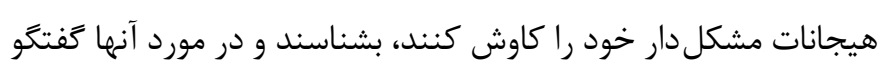

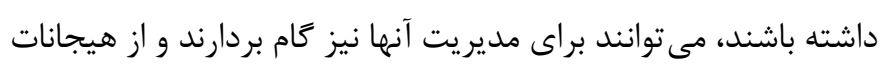

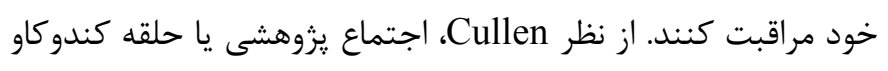

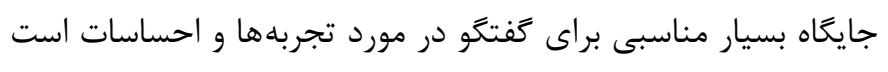

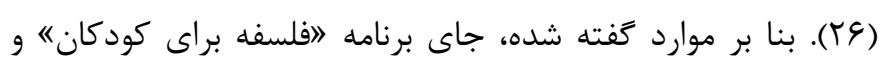

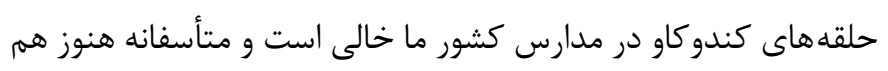

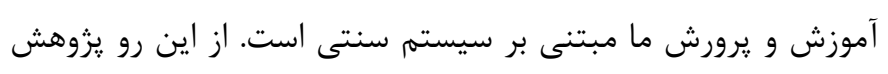

دادهاند. يافته هاى يزوهش نشان داد كه اعتبار و تأثير برنامه فلسفه

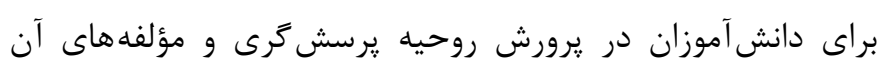

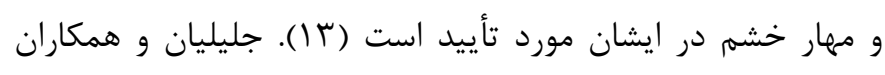

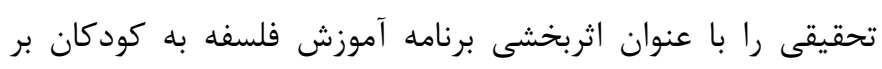

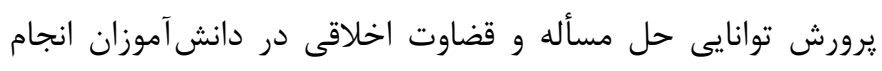

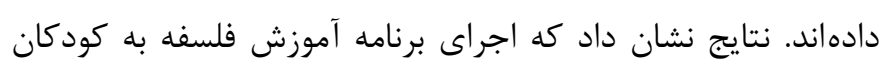

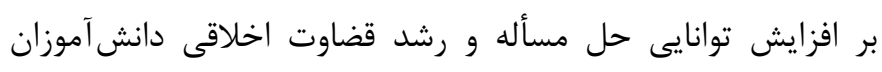

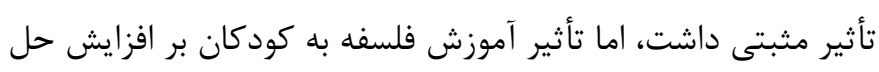

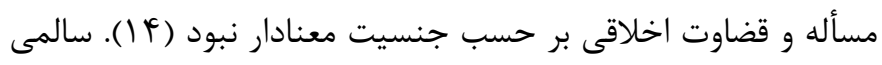

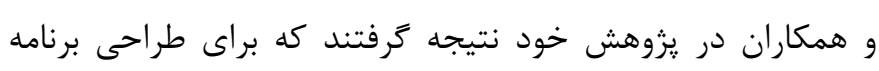

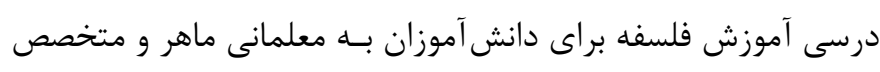

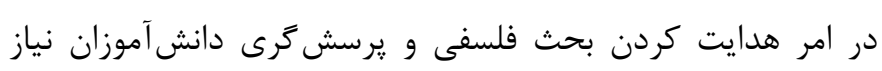

هست (b) (1).

دurris

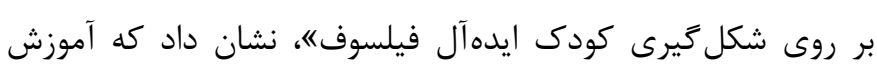

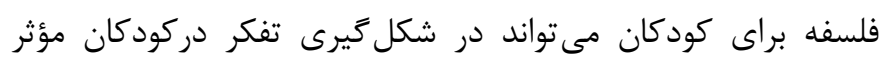

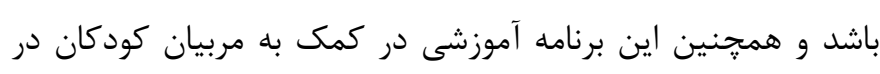

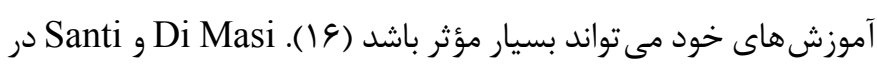

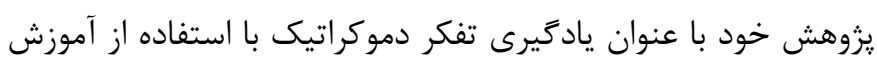

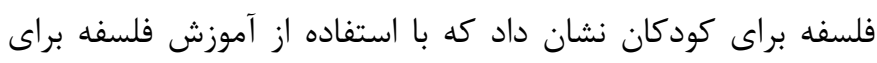

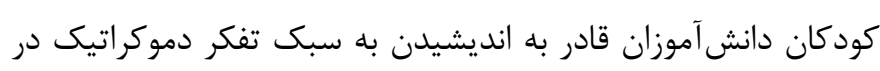

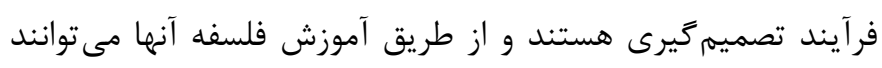

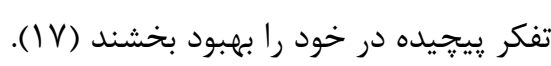

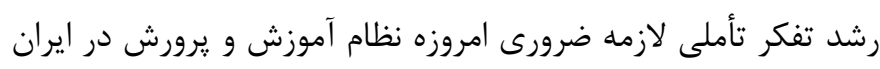

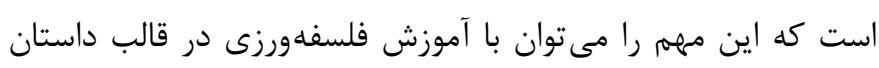

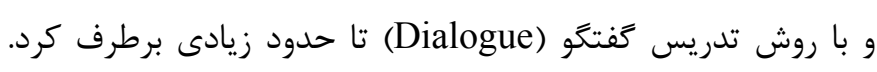

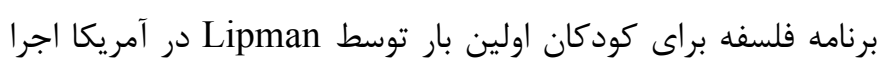

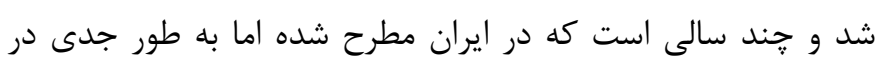

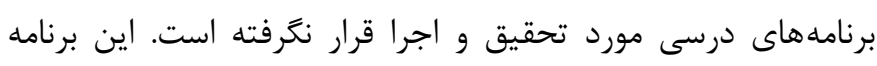

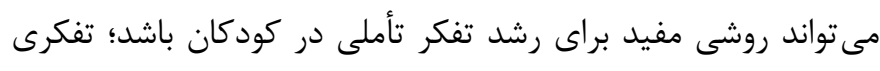

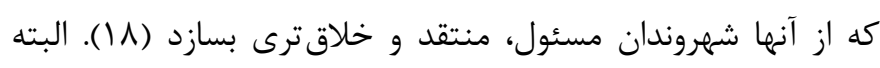
برنامه اصلى فلسفهورزى براى كودكان (فبك)، آموزش فلسفهورزى و و

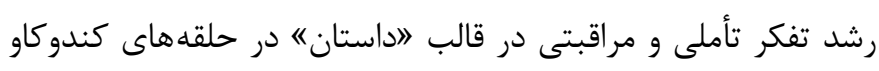

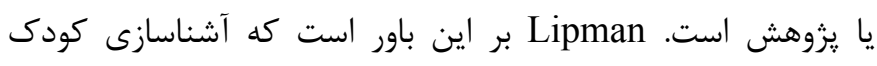

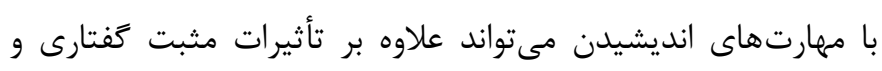

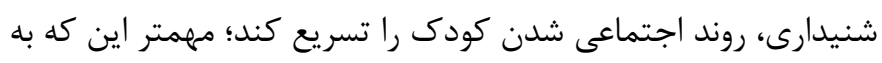
رشد استقلال فكرى، تفكر انتقادى و خلاق در كودكان كمك مى كند. 


\section{يرسشنامه تفكر تأملى}

(Kember Questionnaire for Reflective Thinking)

يرسشنامه تفكر تأملى، اين پرسشنامه توسط Kember و همكاران ساخته

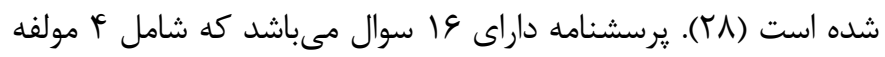
عمل عادتى، فهميدن، تأمل و تأمل انتقادى است. سؤالات يرسشنامه بر اساس طيف ليكرت ينج درجهاى (كاملا موافق نمره ه، تا حدى موافق نمره fا، نظرى ندارم نمره س، تا حدى مخالف نمره ؟، كاملا مخالف نمره ( ) نمرهَذارى مىشود. در اين آزمون محدوديت زمانى وجود ندارد. Kember و همكاران روايى محتوايى يرسشنامه را مناسب ذكر كردهاند. كديور و همكاران يايايى يرسشنامه و مؤلفههاى آن را به روش آلفاى كرونباخ به ترتيب براى مولفه عمل عادتى ه 19.، مؤلفه فهميدن 194. ، مؤلفه تأمل

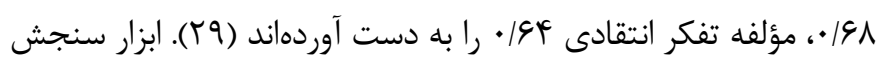
تفكر تأملى براى سن جامعه مورد تحقيق در دسترس نبود، لذا بعضى از كلمات ابزار تفكر تأملى Kember جهت فهم بهـتر دانش آموزان جامعه مورد مطالعه تغيير داده شد. بنابر اين قبل از اجرا، جهت تعيين روايى يرسشنامه، بر روى • ع نفر از دانشآموزان يسر يايه ششم ابتدايى دولتى بخش سنگر اجرا شد و از طريق روايى محتوا مورد سنجش قرار گرفت كه از نظر متخصصين مطلوب ارزيابى گرديد و سؤالات براى دانش آموزان قابل فهرم بود. جهت سنجش يايايى ابزار مورد نظر از ضريب آلفاى كرونباخ استفاده شد، كه ضريب آلفا براى تفكر تأملى /VV/ به دست آمد كه نشان يايايى بالاى يرسشنامه است. همجنين ضريب آلفاى كرونباخ براى مؤلفه

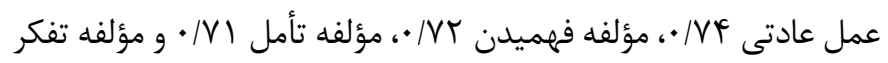
انتقادى V9/ • بود. هر يك از اين مولفهها بيانگر فرآيند تحول و رشد مؤد تفكر از عمل عادتى و درك ارتباط بين فكر و عمل (مولفه عمل عادتى و فهميدن) تا بازنخرى و ارزيابى عملكردها (تفكر انتقادى) و در نهايت به جالش كشيدن و تغيير باورها و عملكرد (مولفه تامل) توسط خود فرد است. بنابراين تفكر انتقادى جزئى از تفكر تأملى است (9).
حاضر بر اساس شواهد موجود، كوششى در پاسخ به اين يرسش است كه آيا آموزش فلسفه به شيوه كفتتويى بر تفكر تاملى دانش آموزان

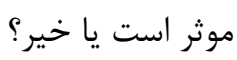

\section{روش كار}

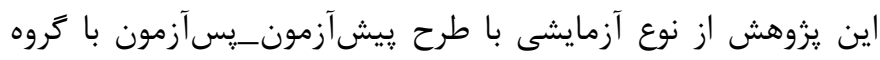

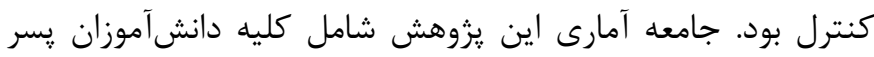

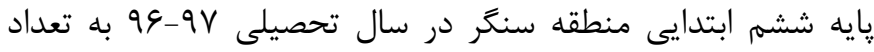

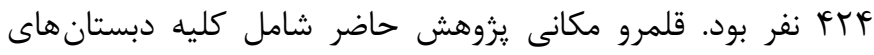
يسرانه بخش سنگر بود و از لحاظ قلمرو موضوعى، در زمينه مباحث علوم تربيتى بود. با توجه به اين كه در يزوهش هاى آزمايشى حداقل

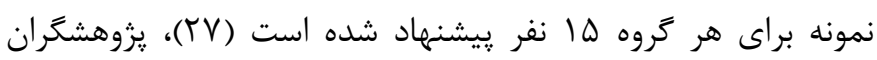
براى اطمينان در اين يزوهش • •ع نفر (براى هر گروه • ب نفر) را وارد مطالعه كردند. در تعيين نمونه از روش نمونه گيرى تصادفى خوشهاى دو مرحلهاى استفاده شد. از بين دبستانهاى روزانه دولتى يسرانه بخش سنگر به صورت تصادفى دبستان ابنسينا انتخاب گرديد، سيس از بين سه كلاس يايه ششم دو يايه انتخاب شد و در نهايت با استفاده از قرعه كشى دو كلاس يكى به عنوان گروه آزمايش و يكى به عنوان

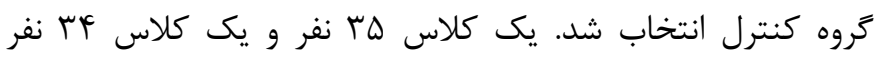
بودند بنابراين از بين هر كلاس به صورت تصادفى • ب نفر را به صورت قرعه كشى انتخاب و در گروهها قرار گرفتند. يرسشنامه تفكر تأملى Kember در بين دانشآموزان توزيع شد. براى ارزيابى تفكر تأملى نسخههاى متفاوتى مانند يرسشنامه سنجش رهبرى تأملى مديران و يا يرسشنامه تفكر تاملى براى معلمان وجود دارد ولى تنها يرسشنامهاى كه تفكر تاملى در دانش آموزان را ارزيابى مى كند و در ايران نيز هنجاريابى شده است، يرسشنامه Kember و همكاران (YF) است كه به شرح زير استفاده شده است.

جدول 1. نغاره طرح تحقيق در يروهش حاضر

\begin{tabular}{|c|c|c|c|c|}
\hline يس آزمون & مداخله & ييش آزمون & انتخاب تصادفى & تروهها \\
\hline $\mathrm{T} 2$ & $X$ & $\mathrm{~T} 1$ & $\mathrm{R}$ & آزمايشى \\
\hline $\mathrm{T} 2$ & - & $\mathrm{T} 1$ & $\mathrm{R}$ & كواه \\
\hline
\end{tabular}

شد همه محرمانه باقى ماند. Y) همه آزمودنى ها براى شركت در يزوهش حق انتخاب داشتند. ץ) به همه شركت كنند
جهت رعايت ملاحظات اخلاقى در اجراى يزوهش موارد فوق رعايت شد: () اطلاعاتى كه در ضمن اجراى تحقيق از شركت كنندكان جمع آورى 
• مرتبط با موضوع صحبت كنند. • به صحبت هم خوب گوش دهند. • در بحث ها مشاركت فعال داشته باشند.

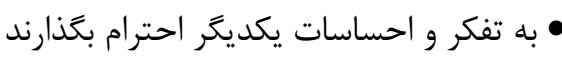
• صرفا ييرامون موضوع و ايدهها متمركز شوند. در بحث كلاسى با هدف كندوكاو، دانشآموزان روى برخى سؤالات، موضوعات، مسائل و ايدهها متمركز مىشوند و مكالمات ييرامون آن شكل مى گيرد. آنان در كشف ايدهها، ممكن است دجار اشتباه شوند، جهت گيرى نادرستى در ييش كيرند و يا به طور كلى مسير بحث را گم كنند و نقاط عطف آن را نبينند. هر جه شركت كنندگان گفتتخو، در كندوكاو بيشتر تجربه كسب كنند، براى حفظ جهت از يكديگر بهره برده و ياد مى گيرند جگكونه اشتباهاتشان را تصحيح كنند و راههاى ديخر رادر نظر بخيرند. لذا در اين فرايند، با تأمل تر و نسبت به صحت كار خود كمتر مطمئن مىشوند، براى تصحيح يك اشتباه آمادگى بيشترى ييدا مى كنند و به خود اجازه تغيير نظر مى دهند. اختلاف نظر در كندوكاو سبب مى شود كودكان به كفتخو بيردازند و در عين حال كه موضوع يا مسئلهاى را به صورت زنده و مهيج بيان مى كنند، علاقهشان نيز افزايش يابد. از طريق تعامل با يكديخر در مورد موضوعهاى مورد علاقه طرفين،

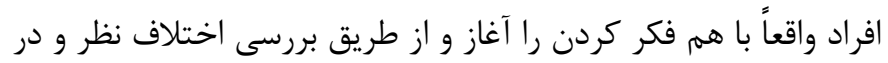
نظر كرفتن دلايلى كه از جنبه هاى مختلف مشاجره مطرح مىشود، در رفتار با يكديخر منطقى تر عمل مى كنند. اين امر به تحكيم هر دو جنبه اجتماع و كندوكاو كمك مى كند. جدول r عناوين داستانها، محتوا و سوالات طرح شده يِرامون موضوع هر داستان را به اجمال در هشت

$$
\text { جلسه نشان مى دهد. }
$$

مقررات گروه، اصل رازدارى در مورد اطلاعات شخصى و مسئوليتهاى

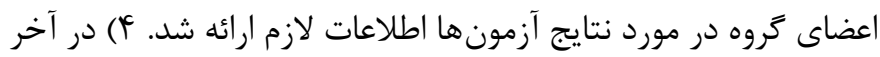
به ياسخ هاى شركت كنند باعث ايجاد يِامدهاى زيان آور براى شركت كنند روش اجرا: ابتدا هر دو گروه آزمايش و كنترل، يرسشنامه تفكر تاملى بيى را تكميل نمودند. سيس به منظور اجراى متغير مستقل، هشت داستان براى كروه آزمايش انتخاب شد كه در هشت جلسه و هر جلسه يك داستان مورد كندوكاو قرار گرفت. داستانها بر اساس ملاكى سنى كودكان و با مراجعه به مجموعه داستانهاى كهن يارسى، مذهبى و ادبيات بينالملل از يزوهشهاى مختلف و مرتبط با تحقيق حاضر انتخاب شدند. محتواى داستان ها در هر جلسه متفاوت بود به طورى كه هر جلسه دانش آموزان با موضوع جديدى آشنا مى شدند و به بحث

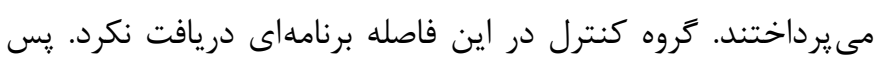
از اتمام جلسه هشتم، مجددا يرسشنامه تفكر تاملى براى هر دو گروه آزمايش و كنترل اجرا شد و دادهها جمع آورى گرديد. در ابتداى جلسه اول يس از معارفه و آشنايى با دانش آموزان، كمى در مورد يزوهش و خصوصا برنامه فلسفه براى كودكان و روش كار در حلقه كندوكاو بحث شد. سيس قوانينى توسط دانش آموزان براى بيشبرد

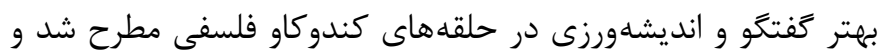
آنان در طول جلسات خود را ملزم به رعايت آنها نمودند از جمله: • هنغام صحبت كردن اجازه بخيرند. • نظرات خود را بلند مطرح كنند. • نظرات يكديخر را مسخره نكنند. • در صورتى كه مطلبى را متوجه نشدند سوال كنند.

جدول r. نغاره طرح تحقيق در يزوهش حاضر

\section{محتوا و سوالات}

داستان

جلسات

داستان در مورد موش تنهايى است كه در كنار آبخيرى زندكى مى كند، روزى قورباغهاى را مى بيند و با او دوست مىشود. موضوع مورد بحث اين داستان مفهوم "دوستى" است. جرا ما با كسى دوست مىشويم؟ اصلاً دوستى موش و قورباغه درست بود؟ با جه كسى بايد دوست شد؟ معيارهاى دوستى جيست؟ دوستى يعنى خه؟ دوستى با آشنايى خه تفاوتى دارد؟ آيا دوستى مىتواند يك طرفه باشد؟ آيا تعداد دوستها مههم است؟ در دوستى خه جيزهايى مههم است؟ آيا دوست ما بايد دقيقاً مثل ما باشد؟ آيا مىشود با كسى كه تفاوت داريم دوست شويم؟ در جه صورت مىشود دوستى را به هم زد؟ در مورد مامون حاكم بغداد است. مامون كه امام رضا (ع) را به شهادت رسانده است در دل مردم ترس و دلهره مى اندازد. مفهوم مورد نظر اين داستان اشجاعته است. تبادل نظر و كَتتكو را مىتوان به سمت پِاسخ به اين گَونه يرسش ها سوق داد: شجاعت جهه معنايى دارد؟ معيار شجاعت جِيست؟ مفاهيم متضاد با شجاعت كدامند؟ آيا پر رويى و بى ادبى كردن، لازمأ شجاعت داشتن است؟ فايدهاى شجاعت جيست؟ آيا شجاعت پِيامدى هم به دنبال دارِ؟ جند نمونه از افراد شجاع

داستان موش و قورباغه

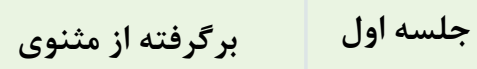
معنوى مولوى

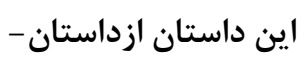
هاى مذهبى اسلامى است كه دانش آموزان جلسه دوم براى آن انتخاب كنند. و معروف را مثال بزنيد. 


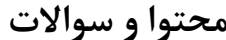

داستان

جلسات

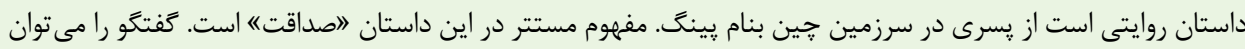
بر محورهاى اين سوالات داير كرد: آيا صداقت، شجاعت نياز دارد؟ آيا بيان هر حرف راستى لازم است؟ زمانى كه كفتن

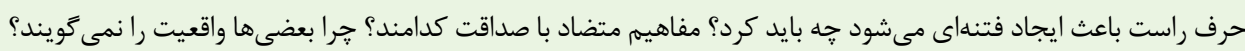
ميان "دروغ كَتن" و "انكفتن حقيقته تفاوتى هست؟ فايدهاى صداقت جيست؟ اخر راستكويى از محبوبيت ما كم كند

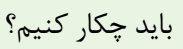

داستان در مورد تولد بوداست. مفهوم كليدى داستان "حقوق حيواناته است. مباحث مورد كندوكاو در اين داستان مى تواند اين كَونه باشد: قاضى حه تصميمى كَفت؟ آيا تصميم قاضى درست بود؟ فكر مى كنيد بودا در مورد قو حهه جيزى به قاضى كفت؟ راه صحيح رفتار با حيوانات جيست؟ آيا انسان حق دارد حيوانات را شكار كند يا بكشد؟ در مورد حيوانات اهلى و دستآموز صحبت كنند. در مورد كونه هاى در حال انقراض صحبت كنند و نام ببرند. داستان روايت يك خركوش بسيار ترسو است كه تفكرات عجيبى دارد. موضوع و هسته اصلى اين داستان لادانشه است. مى توان با كندوكاو به سوالات از اين قبيل رسيد و به آنها ياسخ داد: يرسش كليدى "ادانستن) و "اقبول كردنه يعنى جه؟

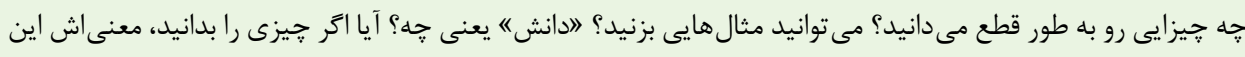

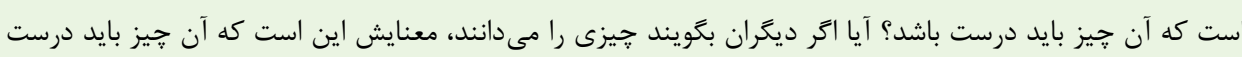

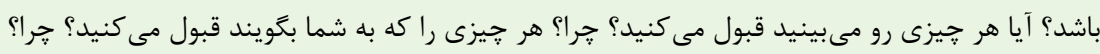

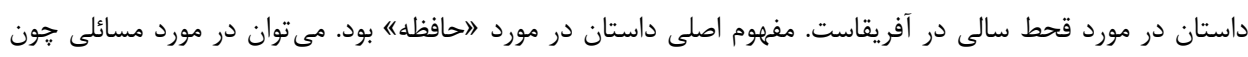

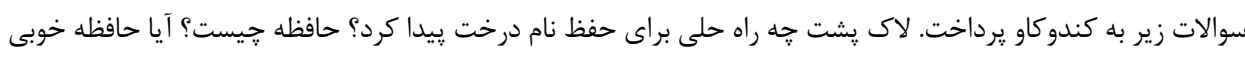

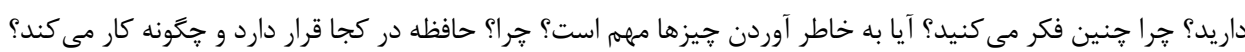
جه جيزى در به ياد آوردن مطالب به شما كمك مى كند؟ جه جيزهايى رو آسان تر به خاطر مى آوريد؟ جرا؟ قصه در مورد يسرى كنجكاو است كه هميشه در حال يرسيدن سوالات تمام نشدنىاش از بدر و مادر خود است. مفهوم

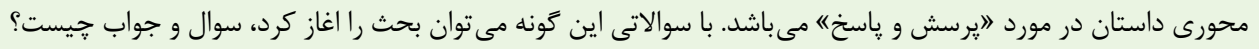

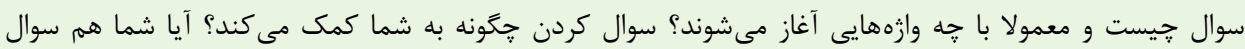
مى كنيد؟ معمولا جه سوالهايى مى كنيد؟ بيت يك پاسخ درست و يك ياسخ غلط جه تفاوتى هايى وجود دارد؟ آيا همه جوابها درست هستند يا غلط؟ داستان در مورد يِيرمرد روستايى فقيرى است كه خانوادَى قايق ران بودهاند. معناو مفهوم داستان كه در مورد "خرده و

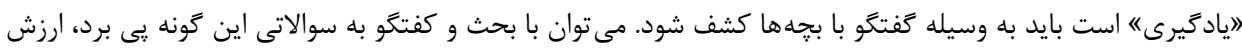

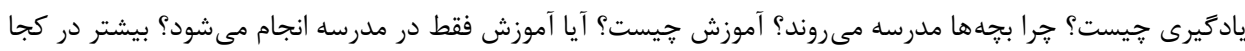
ياد مى كيريد؟ خانه يا مدرسه؟ جرا اين طور فكر مى كنيد؟ آيا بايد بير باشيد تا عاقل باشيد؟ جرا؟ آيا بايد خيلى بدانيد

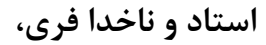

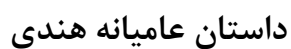

جلسه جهارم بودايى جلسه ينجمم قصه عاميانه هندى

\section{حافظه، قصهاى عاميانه}

از زامبيا

جلسه ششم

يسرى كه هميشه سوال

جلسه هفتم مى كرد، قصهاى عاميانه

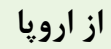
تا عاقل باشيد؟ جه بايد بدانيد تا عاقل شويد؟ موضوعاتى رو كه در مدرسه ياد مى گيرند فهرست كنند و آنها را به ترتيب اهميت قرار دهند، موضوعات مورد علاقه خود را فهرست كنيد، اين فهرستها را با هم مقايسه كنيد و با هم بحث كنيد.

به ميزان F=9/9 و با توجه به اين كه مقدار احتمال از سطح هـ/.

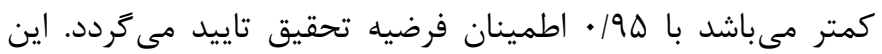
نتايج تجزيه و تحليل دادها با استفاده از آزمونهاى آمار توصيفى نتيجه حاصل مى گردد كه آموزش فلسفهورزى بر رشد تفكر تاملى دانشآموزان ابتدايى تاثير مثبت دارد، در واقع آموزش فلسفهورزى موجب بهبود رشد تفكر تاملى دانش آموزان ابتدايى مى كردد. و استنباطى به شحح جداول ذيل ارائه شده است. همانطور كه در جدول ץ مشاهده مىشود، ميانگين تفكر تاملى گروه آزمايش در

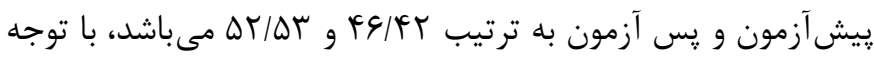


جدول r. ميانكَين و انحراف معيار متغيرهاى تفكر تأملى در كروه آزمايش و كواه

\begin{tabular}{|c|c|c|c|c|c|}
\hline انحراف معيار & ميانغين & تعداد & مرحله & تروه & متغير \\
\hline$V / \cdot 1$ & 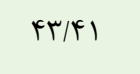 & r. & يِش آزمون & \multirow{2}{*}{ كنترل } & \multirow{4}{*}{ تفكر تاملى } \\
\hline$V / \pi \Delta$ & $F F / V$ & $r$. & يس آزمون & & \\
\hline$V / \cdot \Lambda$ & KE/FT & $r$. & پيش آزمون & \multirow{2}{*}{ آزمايش } & \\
\hline $8 / 19$ & $\Delta T / \Delta T$ & $r$. & يس آزمون & & \\
\hline
\end{tabular}

با توجه به اطلاعات جدول f ملاحظه مى كردد كه مقدار احتمال در مىباشد) كه نشاندهنده نرمال بودن نمرات متغيرهاى تحقيق مى باشد

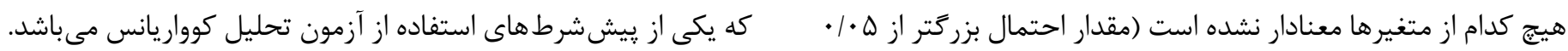
جدول أ. آزمون نرمال بودن دادهها

\begin{tabular}{|c|c|c|c|}
\hline $\mathbf{P}$ & مقدار خطا & $\mathbf{z}$ & متغير ها \\
\hline .1 .99 & $\cdot 1 \cdot \Delta$ & $\cdot 11 \cdot 9$ & تفكر تاملى \\
\hline
\end{tabular}

با توجه به اين كه در آزمون لوين، مقدار احتمال از سطح ه•• بيشتر كروه مورد تاييد است كه يكى ديخر از بيششرطهاى آزمون تحليل

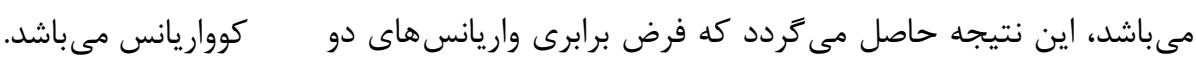
جدول هـ آزمون لوين به منظور بررسى برابرى واريانسها

\begin{tabular}{|c|c|c|c|c|}
\hline مقدار احتمال & خطا & درجه آزادى & مقدار لوين & متغيرها \\
\hline$\cdot 19 \cdot 1$ & $\cdot / \cdot \Delta$ & $\Delta \Lambda, 1$ & $\cdot / 4 V q$ & تفكر تاملى \\
\hline
\end{tabular}

با توجه به اين كه مقدار احتمال از ه•/ • بيشتر مى باشد، بنابراين مى شود و پيش فرض همكونى شيب خط ركرسيون رعايت شده مى توان نتيجه كرفت كه فرضيه صفر مورد قبول و فرضيه مقابل رد است. جدول 9. تعامل متغير مستقل و هميراش

\begin{tabular}{|c|c|c|c|c|c|c|}
\hline مقدار احتمال & آماره فيشر & ميانگين مربعات & درجه آزادى & مجموع مربعات & منابع تغييرات & متغير ها \\
\hline . ITT & $|/ r|$ & $.19 \mathrm{VI}$ & $r$ & $1 / K F$ & حروه و يِيش آزمون & تفكر تاملى \\
\hline
\end{tabular}

مستقل، بايد مقدار F متغير همبراش (كنترل) را حساب كنيم، اكر

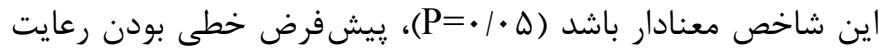

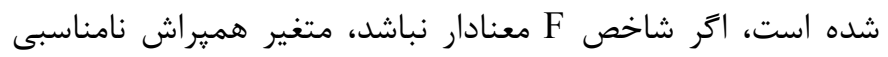
را بركزيدهايم.
ملاحظه مى

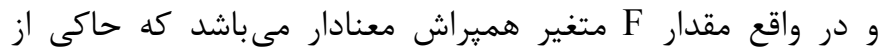
آن است يِشفرض خطى بودن همبستگى متغير همبراش برقرار

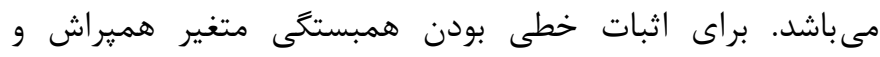


جدول V. تحليل كواريانس يك طرفه

\begin{tabular}{|c|c|c|c|c|c|}
\hline مقدار احتمال & آماره فيشر & ميانگين مربعات & درجه آزادى & مجموع مربعات & متغيرها \\
\hline.$/ \cdot r$ & 1.191 & . $/ N Y I$ & 1 & $\cdot(N Y I$ & تفكر تاملى \\
\hline
\end{tabular}

تاييد مى كردد، بنابراين مى توان كَت آموزش فلسفهورزى بر رشد تفكر تاملى دانش آموزان ابتدايى تاثير مثبت دارد. در واقع آموزش فلسفهورزى كاني موجب بهبود خلاقيت رشد تفكر تاملى دانشآموزان ابتدايى مى گردد.
بررسى فرضيه اصلى: آموزش فلسفهورزى بر رشد تفكر تاملى دانش آموزان ابتدايى تاثير مثبت دارد. با توجه به ميزان

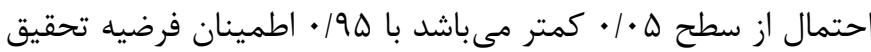

جدول 1. نتايج آزمون آموزش فلسفهورزى بر رشد تفكر تاملى

\begin{tabular}{|c|c|c|c|c|c|c|}
\hline شدت اثر & $\mathbf{P}$ & آماره فيشر & ميانگين مربعات & درجه آزادى & مجموع مربعات & متغيرها \\
\hline \multirow{7}{*}{.$/ T R T$} & $\cdot / . .1$ & $9 / \Delta 9 V$ &. $\mid 94 V$ & r & $1 / 49$ & مدل تصحيح شده \\
\hline &.$/ . .1$ & $|T / V| \mid$ & $\cdot / \Lambda \Delta V$ & 1 & $\cdot / \Lambda \Delta V$ & عرض از مبدا \\
\hline & $\cdot \cdot r$ & $1 \cdot \mid \& 4 \Lambda$ & $\cdot \mid N T I$ & 1 & $\cdot \mid V T I$ & ييش آزمون تاملى \\
\hline & .1 .14 & $9 / 919$ & $.194 \mathrm{~V}$ & 1 & $\cdot \mid \& \& V$ & كروه (متغير مستقل) \\
\hline & & & $.1 .9 \mathrm{~V}$ & $\Delta V$ & $I / A T \mid$ & خطا \\
\hline & & & & 4. & $|A T /| G Y$ & مجموع \\
\hline & & & & $\Delta 9$ & $r / 119$ & كل تصحيح شده \\
\hline
\end{tabular}

رابطه دارد. اين باورها با تأثير در جهار مرحله تفكر تأملى به صورت

مستقيم و غير مستقيم بر رويكردهاى يادگيرى اثرَذار است (9؟). همجنين اين يافتهها با يزوهشهاى Bialystok و همكاران (YF) Gorard مبنى بر اين كه برنامه آموزش فلسفه به مى كوشد تا دانش آموزانى آكاه، منتقد و متفكر يرورش دهد كه در رابطه متقابل با محيط به دانشى

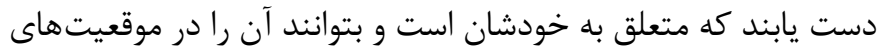
زندگى به كار گيرند، همخوانى دارد. نوروزى و درخشنده در يزوهشى ئس

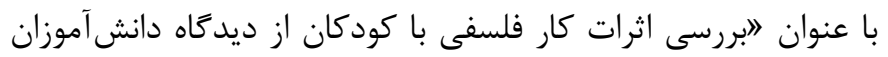
مدارس ابتدايى شهر اصفهان" به بررسى تاثير برنامه فلسفه براى كودى

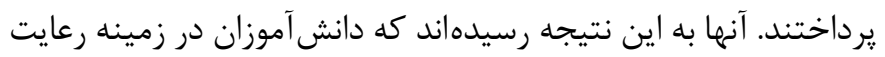
نظم در كلاس، احترام به بزركترها، روابط صحيح با كودكان، درك و

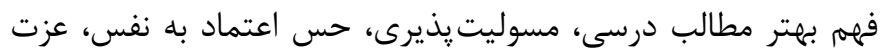
نفس و خلاقيت رشد كرده و برنامه كار فلسفى با آنان در زمينه يِيشرفت تحصيلى مؤثر بوده است (•r). كودكان از طريق مشاركت در استدلال كَروهى، نظريات و عقايد مختلفى را از منابع مختلف فرا مى كيرند.
در يزوهش حاضر به بررسى آموزش فلسفهورزى (روش تدريس كَفتكويى در حلقههاى كندوكاو فلسفى) با محوريت روايت داستان فلسفى بر رشد تفكر تأملى دانشآموزان ابتدايى يرداخته شد. نتايج

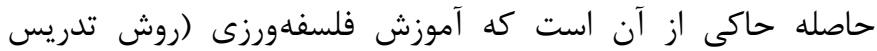
كفتخويى در حلقهاى كندوكاو فلسفى) با محوريت روايت داستان

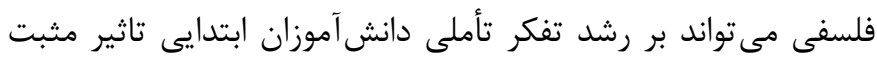

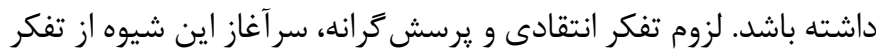

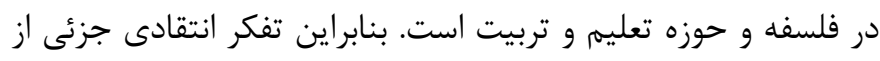
تفكر تأملى است. اين نتايج با يافتههاى مطالعات هدايتى و ماهزاده

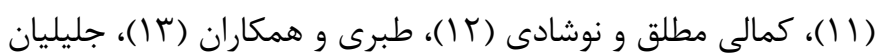

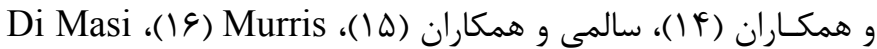
و Santi (IV) همسو است. نتايج اين يزوهشها نيز نشان مى دهد كه آموزش برنامههاى فلسفهورزى براى كودكان و نوجوانان در رشد تفكر

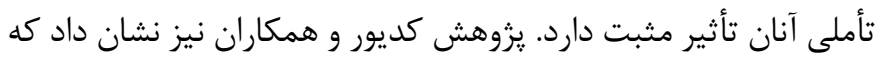
باورهاى معرفت شناختى و رويكردهاى يادگيرى با پيشرفت تحصيلى 
و لازم است كه به ديدكاههاى مختلف احترام كذاشت (Y^). بنابراين

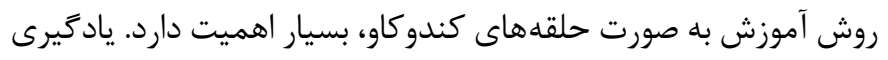

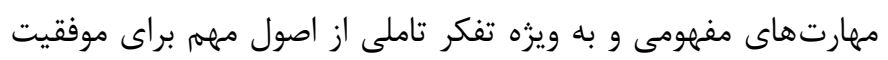

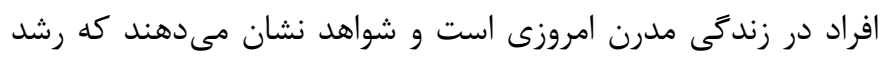

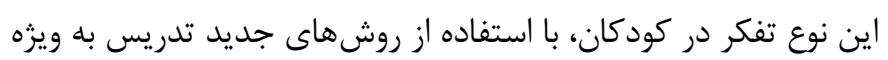
حلقه هاى كندو كاو فلسفى امكان يذير است. هدف اين است كه كود كان بان

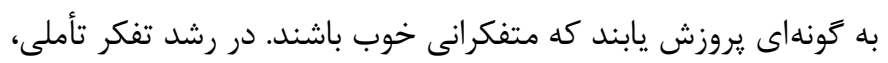

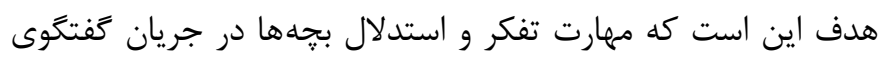

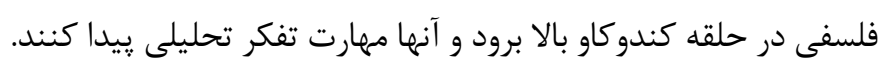

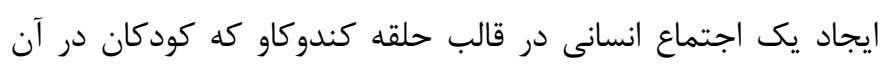

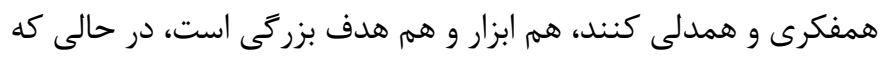

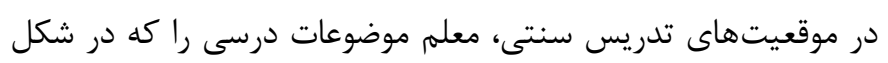

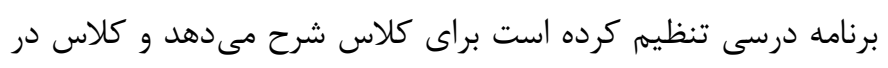

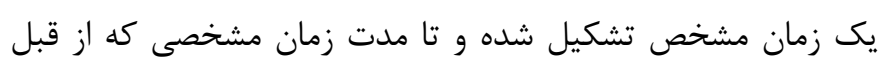

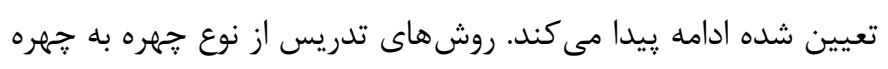

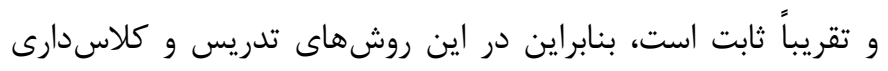

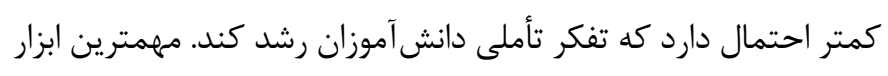

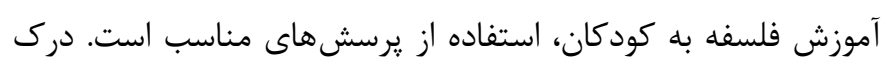
مطلب نيز يكى از مهمترين اهداف كتب فارسى است كه بِيشرفت در آن آن،

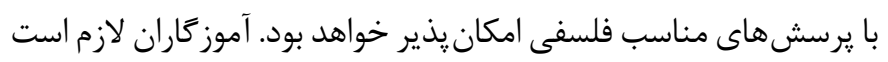
با طرح يرسش فلسفى آشنا شوند تا در تدريس كتب فارسى از آن آن بهره

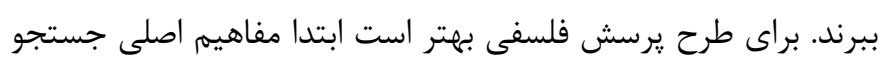

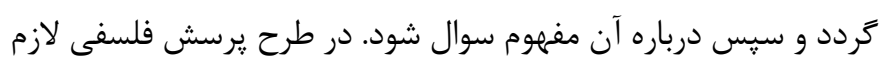

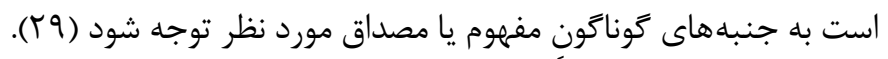

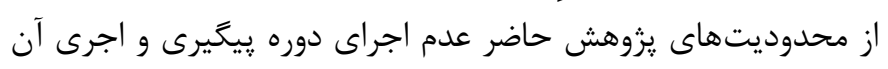

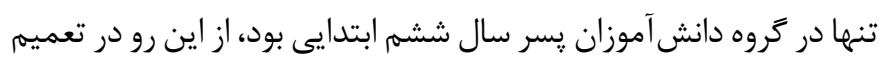

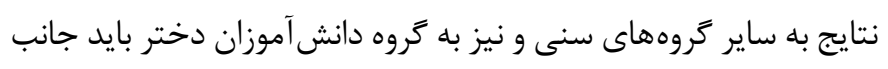
احتياط رعايت شود. همجنين كتاب هاى داستانى كه با هدف فلسفه براي

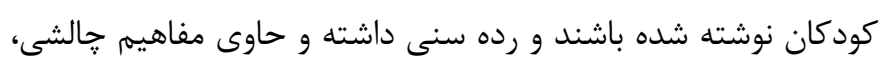
تحليلى و اخلاقى باشند به شدت محدود است. ادبيات كهن ايران بر از از

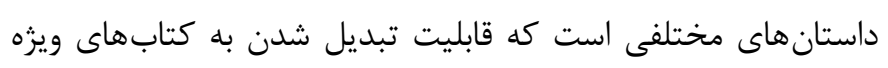

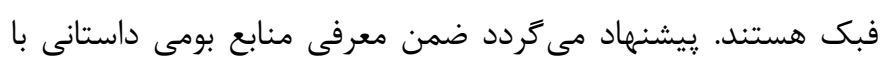

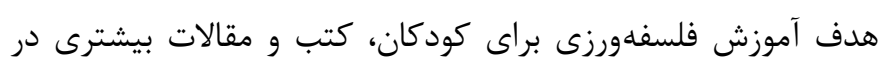

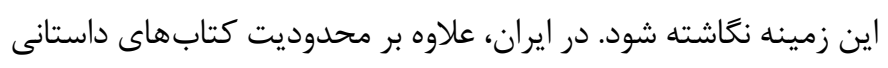

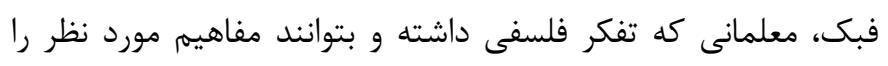

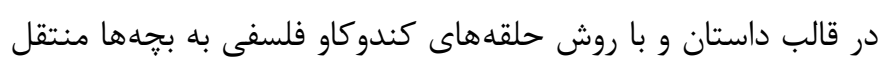
كنند، به شدت محدود است. به عبارتى در ايران عموم معلمان فاقد هنر
آنها يى مى برند كه مى توانند تفكر بهتر و منسجمترى داشته باشند؛

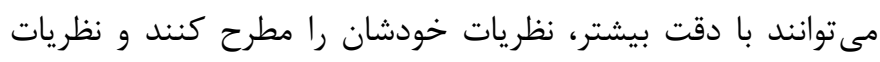

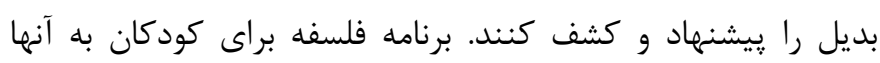

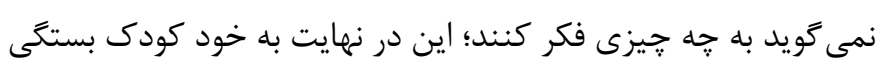

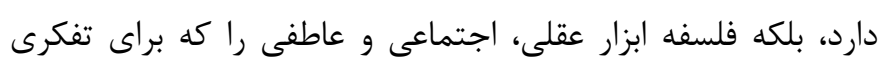

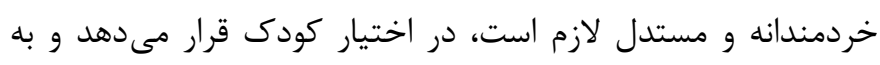
وسيله كاوش گرى جمعى در كلاس، او را ترغيب مى كند تا با تعهد و و شجاعت آن كونه رفتار كند كه فكر مى كنى دند.

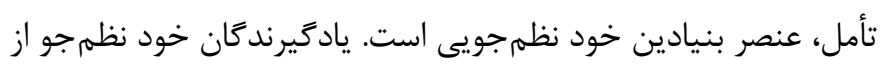

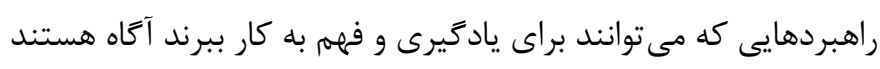

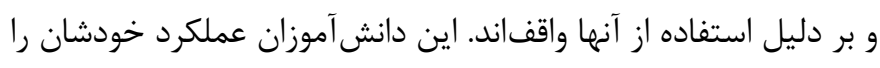

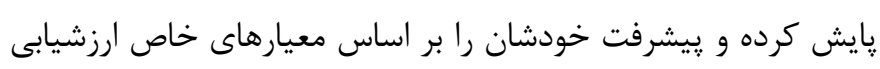

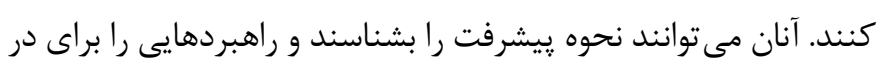

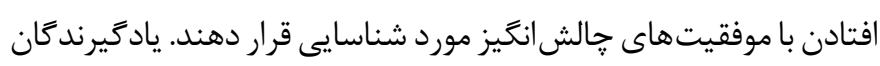

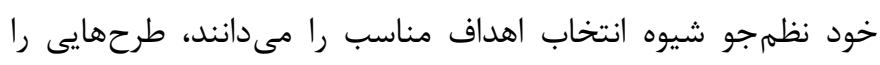

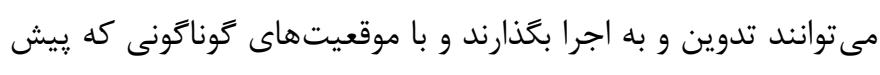

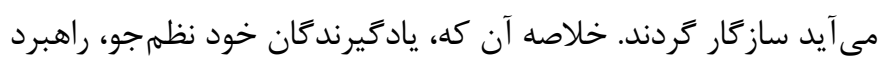

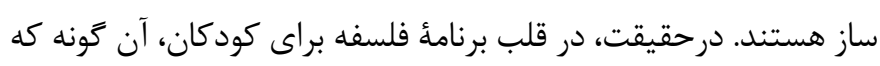

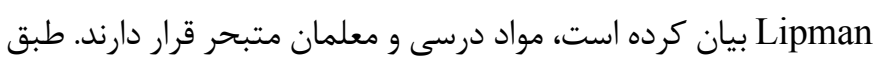

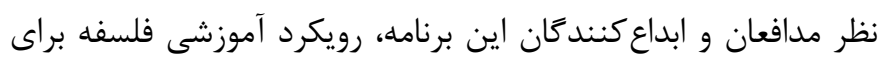

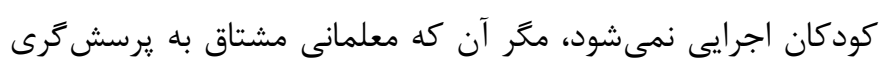

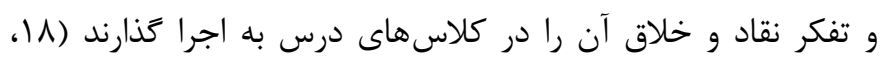

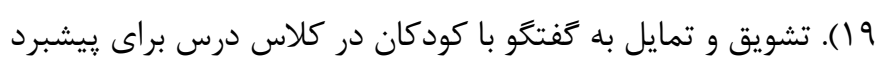

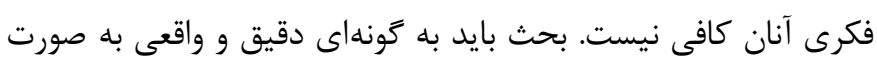

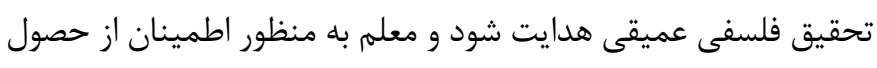

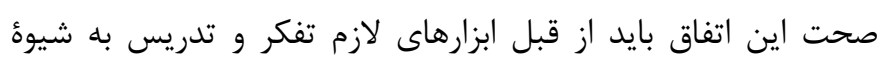

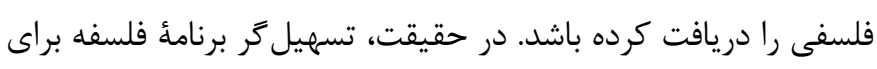

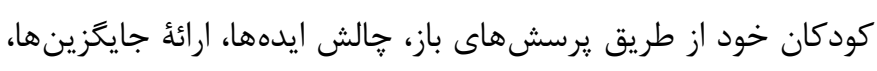

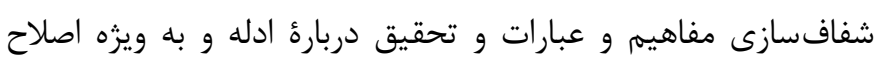

شخصى رفتارهاى خود، الكوى فكرى خوبى به كودكان ارائه مى دهد. در يك روش آموزشى به صورت حلقه هاى كندو كاو فلسفى، دانش آموزان

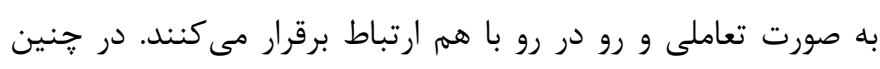

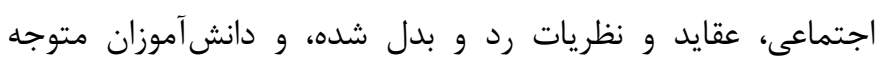
مىشوند كه عقايد و نظريات ديخران، درست همانند نظريات خودشان وندان

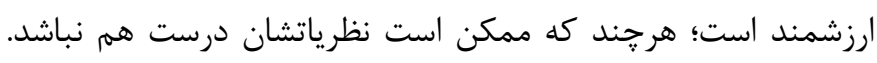

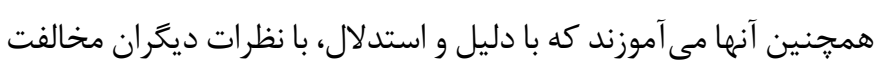

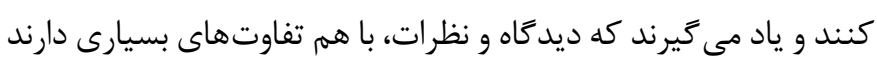


بهببود قدرت استدلال و مهارت تفكر تحليلى دانش آموزان را ايجاد نمود.

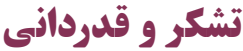

اين يزوهش مستخرج از پاياننامه كارشناسى ارشد آقاى امير نامى

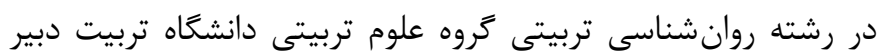
شهيد رجايى مى باشد كه با حمايت مالى و اعتبارى ستاد توسعه علوم و فناورى هاى شناختى با كد 1 انجام شده است. از اين رو از همكارى ستاد، خصوصا كروه تعليم و تربيت شناختى و نيز از زحمات مسئولين و كارشناسان محترم يزوهشى براى هماهنكى هاى انجام شده در اين يزوهش، صميمانه تشكر و قدردانى مىنماييم. همجنين از مديران و مربيان دبستانهاى يسرانه بخش سنكر براى همكارى با يزوهشكَران

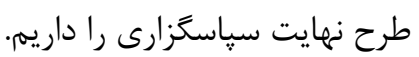

\section{References}

1. Momeni Mahmouei H, Parvaresh E. The impact of the philosophy program for children through the rings to explore creativity, social adjustment and academic achievement science in third grade students. Scientific Journal of Educational Research. 2016;11(47):133-152. (Persian)

2. Nassiri M. The effect of the philosophy curriculum for children on increasing the arguments and creativity skills in the thinking and researching lesson of the sixth primary school students [MSc Thesis]. Gaenat:Islamic Azad University of Gaenat;2014. (Persian)

3. Zarghami S, Sajjadiyeh N, Ghaedi Y. Conceptual redevelopment of "cultivating thinking" as a cultural context of the transformation of the educational system on the basis of human theory as a factor. Journal of Strategic Culture. 2012;5(17):123151. (Persian)

4. Kadivar P, Tanha Z, Rahmani S. Reflective thinking; Exploratory and confirmatory factor analysis. Psychological Research. 2013;16(1):50-64. (Persian)

5. Pamuk O. The naive and sentimental. Gharib A, Translator. Tehran:Negah Publishing Institute;2017. (Persian)

6. Shoari Nezhad A. Philosophy of Education. Tehran:Amir

$$
\text { كندو كاو فلسفى هستند و براى دوره اين كار آموزشى نديدهاند، لذا ييشنهاد }
$$

\section{نتيجبه كيرى}

در اين يزوهش به بررسى تاثير روش تدريس كفتخويى در حلقههاى كندوكاو فلسفى بر رشد تفكر تأملى دانشآموزان ابتدايى يرداخته شد. نتايج حاصله نشان داد كه آموزش فلسفهورزى با محوريت روايت داستان فلسفى مىتواند بر رشد تفكر تأملى دانشآموزان ابتدايى تاثير مثبت داشته باشد. لزوم تفكر انتقادى و يرسش گرانه، سرآغاز اين شيوه از تفكر در فلسفه و حوزه تعليهم و تربيت است. از اين رو با استفاده از برنامههاى آموزشى تفكر محور مىتوان قدرت استدلال دانشآموزان شركت كننده در اين برنامهها را تقويت نمود و امكان

Kabir Publications;2008. (Persian)

7. Hedayati M, Shatalebi A. The effect of logical dialogue in the community of philosophical inquiry on reducing the symptoms of psychosomatic disorders among 11-12-year-old female students in the city of Tehran. Thinking and Children. 2013;4(2):101-116. (Persian)

8. Topping KJ, Trickey S. Impact of philosophical enquiry on school students' interactive behaviour. Thinking Skills and Creativity. 2007;2(2):73-84.

9. Naji S. Handbook of philosopher's folklore for the coaches of the circle of philosophy: A guide for storytelling books for elemental philosophy studies and Hans Christian Andersen stories. Tehran:Publications of the Institute of Humanities and Cultural Studies;2015. (Persian)

10. Omy Z, Gharamaleki F. Comparison of Lipman and Bernie Fair's styles in philosophy for children. Modern Religion Research. 2005;1(2):7-24. (Persian)

11. Hedayati M, Mahzadeh H. Philosophy for children and social problem-solving skills. Journal of Educational Sciences, 2016;23(1):29-54. (Persian)

12. Kamali Motlagh T, Noushadi N. The impact of teaching phi- 
losophy to children using native stories in elementary students' ethical development. Thinking and Children. 2017;8(1):1-13. (Persian)

13. Tabari M, Khaleqkhah A, Moradi M, Zahed Babolan A. The effect of teaching philosophy and child on the morale of questioning and anger in students. Thinking and Children. 2017;4(3):19-38. (Persian)

14. Jalilian S, Azimpour E, Jalilian F. The effectiveness of philosophy for children program (P4C) on the problem-solving abilities and moral judgment of students. Educational Researches. 2017;3(32):80-101. (Persian)

15. Salemi Y, Mojalal Choobeghlou MA. Hojjati SA. Identifying the requirements for designing a curriculum for the teaching of philosophy for children from the viewpoint of primary school teachers in the city of Bonab. Thinking and Children. 2018;9(2):71-92. (Persian)

16. Murris K. The philosophy for children curriculum: Resisting 'teacher proof 'texts and the formation of the ideal philosopher child. Studies in Philosophy and Education. 2016;35(1):63-78. 17. Di Masi D, Santi M. Learning democratic thinking: A curriculum to philosophy for children as citizens. Journal of Curriculum Studies. 2016;48(1):136-150.

18. Lipman M. Promoting better classroom thinking. Educational Psychology. 1993;13(3-4):291-304.

19. Lipman M. Thinking in Education. 2nd ed. Cambridge:Cambridge University Press;2003.

20. Gazzard A. Emotional intelligence: Does philosophy have a part to play?. Analytic Teaching. 2002;21(2):140-150

21. Barrow W. 'I think she's learnt how to sort of let the class speak': Children's perspectives on philosophy for children as participatory pedagogy. Thinking Skills and Creativity. 2015;17:76-87.
22. Valitalo R, Juuso H, Sutinen A. Philosophy for children as an educational practice. Studies in Philosophy and Education. 2016;35(1):79-92.

23. Fair F, Haas LE, Gardosik C, Johnson DD, Price DP, Leipnik O. Socrates in the schools from Scotland to Texas: Replicating a study on the effects of a philosophy for children program. Journal of Philosophy in Schools. 2015;2(1):18-37.

24. Bialystok L, Norris T, Pinto LE. Teaching and learning philosophy in Ontario high schools. Journal of Curriculum Studies. 2019;51(5):678-697.

25. Gorard S, Siddiqui N, See BH. Can 'Philosophy for Children' improve primary school attainment?. Journal of Philosophy of Education. 2017;51(1):5-22.

26. Cullen J. Using philosophy for children as a means of fostering high quality learning and teaching: Can using a 'Question Quadrant' help children at Key Stage 1 ask higher-order questions?. The STEP Journal: Student Teacher Perspectives. 2016;3(2):24-34.

27. Chohen L, Manion L. Research methods in education. 6th ed. London:Rutledge;2000.

28. Kember D. Determining the level of reflective thinking from students' written journals using a coding scheme based on the work of Mezirow. International Journal of Lifelong Education. 1999;18(1):18-30.

29. Kadivar P, Tanha Z, Farzad V. The relationship between epistemological beliefs, learning approaches, reflective thinking and academic achievement. Journal of Psychology. 2012;16(3):251-265. (Persian)

30. Nowrozi RA, Derakhshande N. Investigating the influence of philosophical work with children from the primary school student's viewpoints. Educational Innovations. 2008;6(4):123147. (Persian) 